\title{
İmalat İ̧̧letmelerinde İş Sağlığı ve İ̧̧ Güvenliği Üzerine Bir Araştırma: Tuğla Fabrikaları Örneği
}

\author{
A Research on Occupational Health and Safety in Manufacturing Enterprises: \\ The Case of Brick Factories
}

\author{
Ergin TEMEL (D) , Uğur ÇAKIR (D) , Fuat Ferit YAZAR
}

\begin{abstract}
ÖZET
Çalışmanın amacı tuğla fabrikalarında iş sağlığı ve iş güvenliğine yönelik alınan tedbirlerin işçiler tarafından uygulanma düzeylerini ölçmek ve işçilerde ortaya çıkan sağlık problemlerini tespit etmektir. Çalışmanın verileri TR 83 bölgesinde yer alan Erbaa'daki tuğla fabrikalarında çalışan 168 işçi ile yapılan anket yöntemiyle elde edilmiştir. Anket sorularında çalışanların yaş, cinsiyet, eğitim durumu gibi demografik sorularla iş kazası ve meslek hastalıkların önlenmesine yönelik periyodik sağlık taramasının yapılıp yapılmadığı, işyerlerinde ilk yardım çantasının bulması, işçilerin eldiven, maske, kulak tıkacı, koruyucu gözlük kullanmaları gibi sorular sorularak işçilerin iş kazası ve meslek hastalıkların önlenmesine yönelik uygulamalara uyup uymadığı ve ortaya çıkan sağlık problemleri araştırılmıștır. Araştırma sonucunda çalışanların \%95'nin erkek, \%70'nin 31-50 yaş aralığında, \%84'nün ilköğretim düzeyinde eğitimi olduğu, işçilerin işe başlamadan önce sağlık taramasından geçirildiği, bütün fabrikalarda tehlikeli alanlar için uyarı levhalarının olduğu, işçiler tarafından maske kullanım oranının \%27, eldiven kullanım oranının \%73 olduğu, maske kullanım oranının az olmasına bağlı olarak solunum yolu rahatsızlıklarının ortaya çıktığı tespit edilmiştir.

Anahtar Kelimeler: İș Sağlığı, İș Güvenliği, Meslek Hastalı̆̆ı, İş Kazası, İş Güvenliği Tedbirleri.

\section{ABSTRACT}

The aim of the study is to measure the level of implementation of the measures taken for occupational health and safety at the brick factories by the workers and to identify the health problems that arise in the workers. The data of the study were obtained through a survey method conducted with 168 workers working in brick factories in Erbaa district in TR 83 region. In the survey questions, the workers are asked for questions such as whether the periodic health screening is done for the prevention of occupational diseases and occupational diseases with demographic questions such as age, gender, educational status, finding the first-aid kit in the workplaces, the use of gloves, masks, ear plugs, and protective glasses for workers. Whether they comply with practices for preventing diseases and emerging diseases were investigated. As a result of the research, $95 \%$ of the employees are male, $70 \%$ are between the ages of 31-50, 84\% of them have primary education, workers are screened before they start work, there are warning signs for hazardous areas in all factories, mask usage rate by workers It was determined that $27 \%$ of the glove usage rate was $73 \%$, that respiratory tract disorders occur due to the low rate of mask use.

Keywords: Occupational Health, Occupational Safety, Occupational Disease, Occupational Accident, Occupational Safety Measures.
\end{abstract}

Ergin TEMEL | ergin.temel@gop.edu.tr

Tokat Gaziosmanpaşa Üniversitesi, Erbaa sağlık bilimler fakültesi, Sağlık Yönetimi Bölümü, Erbaa, Tokat, Türkiye

Tokat Gaziosmanpaşa University, Erbaa Faculty of Health Sciences, Department of Health Management, Erbaa, Tokat, Turkey

Uğur ÇAKIR I ugur.cakir@gop.edu.tr

Tokat Gaziosmanpaşa Üniversitesi, Erbaa Meslek Yüksekokulu, Tasarım Bölümü, 60500, Erbaa, Tokat, Türkiye

Tokat Gaziosmanpaşa University, Erbaa Vocational School, Department of Design, 60500, Erbaa, Tokat, Turkey

Fuat Ferit YAZAR I fuatferit.yazar@gop.edu.tr

Tokat Gaziosmanpaşa Üniversitesi, Erbaa Meslek Yüksekokulu, Muhasebe ve Vergi Uygulamaları Bölümü, Türkiye

Tokat Gaziosmanpaşa University, Erbaa Vocational School, Department of Accounting and Tax Applications, Erbaa, Tokat, Turkey 


\section{GİRIŞ}

İşs sağlığı ve iş güvenliği, işin yapılması ve yürütülmesi sürecinde meydana gelen tehlikelerden ve sağlığa zarar verebilecek koşullardan çalşanları korumak ve daha iyi bir çalışma ortamı sağlamak için yapılan sistemli çalışmalar olarak tanımlanmaktadır [13]. İş sağlığı ve iş güvenliği ile çalışanların, çalışma ortamlarında karşılaşacakları tehlikelerden ve sağlıklarında oluşacak zararlardan korunması amaçlanmaktadır.

Dünyada ve ülkemizde sanayileşme ve teknolojik gelişmelerle birlikte çalışma alanlarında çalışanların sağlığı ve güvenliği ile ilgili iş kazaları başta olmak üzere birtakım sağlık sorunları ortaya çıkmışıır [1]. Üretim teknolojilerinin ve üretimde kullanılan yöntemlerin gelişmesi ve üretimde sermaye yoğun üretime geçilmesi çalışanların üretim sürecindeki etkinliğini azaltmıştır. Ancak teknolojik gelişmeler her sektörde aynı seviyede gelişmemiş ve emek yoğun üretime devam eden sektörlerde bulunmaktadır. Hem emek yoğun hem de sermaye yoğun üretim yapan işletmelerde çalışan işçiler iş sağlığı ve güvenliği açısından çeşitli risklerle karşı karşıyadır.

İş kazaları ve meslek hastalıkları için uluslararası çalışma örgütünün açıklamış olduğu verilere göre, her 15 saniyede 160 çalışan iş kazası geçirmekte ve her gün yaklaşık 6 bin 400 çalışan iş kazası veya meslek hastalıkları nedeniyle yaşamını yitirmektedir. Yine açıklanan verilere göre, her yıl yaklaşık olarak 350 bin çalışan iş kazası, 2 milyon çalışanda meslek hastalıkları nedeniyle yaşamını yitirmektedir. Her yıl yaklaşık olarak 270 milyon iş kazası meydana gelmekte ve 160 milyon kişide meslek hastalıklarına maruz kalmaktadır [22].

2018 yılı Sosyal Güvenlik Kurumu (SGK) verilerine göre ülkemizde 431.276 iş kazası meydana gelmiş, 1.047 çalışan meslek hastalığına yakalanmıştır. İş kazalarında
1.542 çalışan hayatını kaybetmiş, 4.067 çalışana sürekli iş göremezlik geliri bağlanmıştır [6].

İş kazası ve meslek hastalıkları ile ilgili hem ulusal hem de uluslararası veriler incelendiğinde iş kazası ve meslek hastalığı sayılarının azımsanamayacak miktarda olduğu görülmektedir. İş kazası ve meslek hastalıklarının önlenmesi, işçi sağlığı ve iş güvenliğinin sağlanması için hem işverenlere hem de işçilere önemli sorumluluklar düşmektedir. İşverenlerin işyerlerinde iş kazalarının ve meslek hastalıklarının oluşmasına neden olacak etkenler için gerekli tedbirleri almaları, işçilerinde alınan tedbirlere uymaları gerekmektedir.

Bu çalışmanın amacı tuğla fabrikalarında iş sağlı̆̆ı ve iş güvenliğine yönelik alınan tedbirlerin iş̧̧iler tarafından uygulanma düzeylerini ölçmek ve işçilerde ortaya çıkan sağlık problemlerini tespit etmektir. Çalışmada öncelikle kavramsal çerçeve anlatılmış ve TR 83 bölgesinde yer alan Tokat ili Erbaa ilçesinde faaliyette bulunan tuğla fabrikalarında işçi sağlğ̆ı ve iş güvenliği için alınan tedbirler, uygulanma düzeyleri ve iş̧̧ilerde ortaya çıkan sağlık problemleri incelenmiş̧ir.

\section{KAVRAMSAL ÇERÇEVE}

\section{A. İş Sağlığı ve İş Güvenliği}

İş sağlığı ve iş güvenliği kavramları birlikte anılan bir kavramdır. Çalışma ortamları için önem arz eden bu iki kavramın temel amacı, iş kazaları ve meslek hastalıkları gibi çalışanların işyerlerinde karşılaşacakları tehlikeleri önleyip, sağlıklarını ve yaşamlarını korumaktır [4].

Dünya sağlık örgütü sağlığı, yalnızca hastalık ya da sakatlığın bulunmaması değil aynı zamanda bedensel, ruhsal ve sosyal olarak tam bir iyilik hali olarak tanımlamıştır [2]. Yani, dünya sağlık örgütü sağlığı sadece bedensel iyilik değil aynı zamanda ruhsal ve sosyal yönde de iyi olunması- 
nı ifade etmektedir.

İş sağlığını, tüm çalışanların çalıştıkları iş ortamında ruhsal ve bedensel olarak sağlı̆g 1 etkileyen mevcut veya olası risk faktörlerine karşı korunmalarını, çalışma koşullarının ve üretim araçlarının sağlığa uygun hale getirilmesini, iş ve üretim araçları ile çalışan arasındaki uyumun sağlanmasını amaçlayan kurallar bütünü olarak tanımlanmaktadır [10]. İş sağlığı kavramı çalışanlarla birlikte çalışanın zarar görmesinden etkilenen onun sosyal çevresini, işletmenin ilgili olduğu tüm çevreyi ve de toplumu kapsayan geniş bir kavramı ifade etmektedir [5]. İş sağlığı sadece işçinin kendisiyle sınırlı olmayıp, kendisiyle birlikte yakın ve uzak çevresini de ilgilendiren çok yönlü etkiye sahip olan bir kavramdır.

İş sağlığı, çalışanların çalışma ortamında kullandıkları araç ve gereçlerden doğabilecek tehlikelerden arınmış veya bu tehlikelerin en az düzeye indirilmiş bir iş ortamında düşük stresle hayatını devam ettirmesi olarak da tanımlanmıştır [23]. İş sağlığının sağlanması için çalışma ortamında kullanılan araç ve gereçlerin oluşturacağı zararın ortadan kaldırılması gerekmektedir.

İş güvenliği, güvenli bir çalışma ortamı içerisinde gereken teknik kuralları ifade etmektedir. Her işyerinde işin yapılması sırasında kullanılan araç ve gereçlerin çalışmaları sırasında ortaya çıkabilecek bazı riskler vardır. İş güvenliği çerçevesinde işverenler oluşacak riskleri belirlemeli, tehlikelerin oluşumunu engelleyecek tedbirleri almalı ve çalışalar tarafından uygulanmasını sağlamalıdır.

Çalışma ortamının planlaması ve inşası, makinelerin yerleşim düzeni, montajı ve işleyişi ile ilgili her konu iş güvenliğini ilgilendirmektedir. Bu kapsamda iş güvenliği, işin yapılması sırasında kullanılan araç, gereç ve diğer ekipmanların kullanım nedeniyle doğabilecek tehlikeler ile çalışanın hayatına ve vücut bütünlüğüne yönelik ortaya çıkacak teknik nitelikli tehlikelere karşı korunmasını ifade eder [10].

Dünya Sağlık Örgütü (WHO) ve Uluslararası Çalışma Örgütü (ILO) işçi sağlığı ve iş güvenliğini, tüm çalışanların bedensel, ruhsal ve toplumsal sağlık düzeylerinin en üst seviyeye çıkarılması ve bu durumun korunması için, işyeri koşullarının, çevrenin ve üretilen malların oluşturacağı olumsuz durumların ortadan kaldırılması, çalışanları yaralanmalara ve kazalara maruz bırakacak risk faktörlerinin ortadan kaldırılması, çalışanların bedensel ve ruhsal özelliklere uygun işlere yerleştirilmesi olarak tanımlamaktadır [8]. İş güvenliği kurallarına yeterli özenin gösterilmemesi, iş kazası ve meslek hastalıklarının ortaya çıkmasının ana nedenini oluşturmaktadır [15]. İşçi sağlı̆̆ının ve güvenliğinin sağlanması için yasalar ve iş sağlı̆̆ı ve güvenliği uzmanları tarafından belirlenen tedbirlerin alınıp iş yerlerinde uygulaması gerekmektedir.

\section{B. Meslek Hastalığı}

Meslek hastalığın tanımını ILO, zararlı bir etkenle bundan etkilenen insan vücudu arasında, çalışılan işle bağlantılı olarak bir neden-sonuç yada etki-tepki ilişkisinin ortaya konabildiği hastalıklar grubu olarak, WHO ise, yalnızca bilinen ve kabul edilen meslek hastalıkların değil, aynı zamanda onun oluşmasında ve gelişmesinde, çalışma ortamının ve çalışma şeklinin sebepler arasında önemli bir faktör olduğu hastalıklar olarak tanımlamıştır [18].

5510 sayılı Sosyal Sigortalar ve Genel Sağlık Sigortası Kanunu'nun 14. maddesi meslek hastalığını, çalışanın çalıştı̆̆ı iş yerinin veya yaptığı işin niteliğinden dolayı tekrarlanan bir sebeple veya işin yürütüm şartlarına bağılı olarak meydana gelen geçici veya sürekli hastalık, bedensel veya ruhsal engellilik halleri olarak tanımlamıştır [14]. Tanımlardan anlaşıldığı üzere meslek hastalığı, yapılan işlerin tekrarlanarak yapılmasından kaynaklanan, yapılan iş ile neden sonuç ilişkisi kurulabilen, çalışanların sağlığında 
geçici veya sürekli bedensel ve/veya ruhsal hastalıkları ifade etmektedir.

Çalışma şartlarına ve iş türünün özelliğine göre çok çeşitli meslek hastalıkları ortaya çıkmaktadır. Meslek hastalıklarının ortaya çıkmasında genellikle iş sağlık ve güvenliği kurallarının yetersiz uygulanmasında ortaya çıkmaktadır [11]. Yapılan işle veya çalışma ortamıyla ilgili olarak ortaya çıkan en yaygın meslek hastalıkları ve sağlık sorunlarına, tehlikeli maddelerin açıklığından ileri gelen kanser türleri, iskelet-kas bozuklukları, solunum yolu hastalıkları, işitme kaybı, dolaşım yolu bozuklukları ve bulaşıcı hastalıklar örnek gösterilebilir [5]. Çalışanlarda ortaya çıkacak meslek hastalıkları iş yerlerinin faaliyette bulunduğu sektörlere ve çalışma şartlarına bağlı olarak farklılık göstermektedir. Örneğin, madenlerde (kömür, bakır, antimon) çalışanlarda solunum yolu hastalıkları, kimyevi işletmelerde (boya, ilaç) solunum yolu ve cilt hastalıları, tekstil işletmelerinde iskelet kas, solunum yolu ve işitme kaybı hastalıkları, döküm işletmelerinde solunum yolu ve cilt hastalıkları gibi mesleki hastalıklar ortaya çıkmaktadır.

\section{C. İş Kazası}

İş kazasını, 6331 sayılı İş Sağlığı ve Güvenliği Kanunu'nun 3.maddesi, işyerinde veya işin yapılması sırasında ortaya çıkan, ölümle sonuçlanan veya vücut bütünlüğünü ruhen ya da bedenen engelli duruma getiren olay olarak tanımlamıştır [9]. Bu tanıma göre bir olayın iş kazası olabilmesi için işyerinde veya işin yürütümü esnasında ortaya çıkması ve olayın sonucunda ölüm veya vücut bütünlüğünü ruhen veya bedenen etkilemesi gerekmektedir.

5510 sayılı Sosyal Sigortalar ve Genel Sağlık Sigortası Kanunu (SSGSSK)'nun 13. maddesi iş kazası olacak hususları açıklamıştır [14]. Bu maddeye göre iş kazası sayılacak hususlar;

a) Sigortalının işyerinde bulunduğu zaman diliminde, b) İşveren adına yürütülmekte olan iş nedeniyle sigorta1 kendi adına ve hesabına bağımsız olarak çalışıyorsa yürütmekte olduğu iş nedeniyle,

c) İşverene bağlı olarak çalışan sigortalının, görevli olarak işyeri dışında farklı bir yere gönderilmesi nedeniyle asıl işini yapmaksızın geçen zamanlarda,

d) Emziren kadın sigortalının, iş mevzuatı gereğince çocuğuna süt vermek için ayrılan zamanlarda,

e) Sigortalının, işveren tarafından sağlanan bir taşıtla işin yapıldığı yere gidiş gelişi sırasında, meydana gelen ve sigortalı çalışanda hemen veya daha sonra bedenen ya da ruhen engelli hale getiren olaylar olarak açıklanmaktadır [16]. Tanımdan da anlaşıldığı üzere bir kazanın iş kazasının olması için bir işveren adına bir işyerinde işin yapılması sırasında olması şart değildir, görev yeri dışında (iş servisinde, süt izni sürecinde, farklı yerde görevlendirilmesi) olması $\mathrm{da}$ iş kazası için geçerli gerekçe olarak kabul edilmektedir.

İş kazaları, çalışanların çalışma esnasındaki gerekli olan dikkati göstermediklerinden, bilinçli çalışma sergilemediklerinden, disiplinsiz davranışlarda bulunduklarından, güvensiz çalışma yöntemlerinden, uygun olmayan veya bakımsız alet ve makine kullanımından dolayı meydana gelmektedir. Çalışanların tehlikelere karşı gereken özeni göstermemesi, eğitimsizlikleri, psikolojik sorunları, yorgunlukları da iş kazalarının meydana gelmesine neden olmaktadır [18]. İşverenlerin de arızalı, işe uygun olmayan, bakım yapılmamış araç ve gereçlerin iş yerlerinde kullandırmaları ve kazaları önleyici gerekli tedbirleri almamaları nedeniyle de iş kazaları oluşmaktadır. İşverenler işyerlerinde iş kazalarını engelleyecek tehlike levhalarını asmaları, traktör ve loder çalışma alanlarına izinsiz girilmeyeceği uyarısında bulunmaları, kamara dolum ve boşaltımlarında eldiven kullanımlarını sağlama gibi tedbirleri almaları, çalışanların da bu tedbirlere ve tehlike uyarılarına uymaları gerekmek- 
tedir.

\section{TUĞLA ÜRETIMI VE İŞÇİ SAĞLIĞI}

Tuğla fabrikalarında üretim, safha üretim sistemine göre yapılmaktadır. Tuğla üretimi birbirine bağlı aşamalardan geçerek oluşmaktadır. Her aşamada yapılan üretim işlemleri ve üretimde kullanılan makinalar değişmektedir [20]. Temelde tuğla fabrikalarında üretim aşamaları hammadde hazırlama, şekillendirme, kurutma ve pişirmedir.

Hammadde hazırlama üretimin sürecinin başlangıcıdır. Bu aşamada, üretimin hammaddesi olan toprağın işlenebilir özelliği kazanabilmesi, homojen bir malzeme olması, plastiklik ve kohezyon özelliklerine sahip olması için [17] tezek kırıcı, taş ayırıcı, ezici valsler ve karıştıııı gibi çeşitli makinelerde işlem görmektedir [19]. Bu aşamada çalsşan işçiler toprak tozuna ve makine gürültüsüne maruz kalmaktadırlar.

Şekillendirme aşaması, toprağa tuğla şekli verildiği aşamadır. Bu aşamada Prese giren toprak presin çıkışında bulunan kalıplar sayesinde tuğla şeklini almaktadır. Tuğla şekli alan yarı mamul (çiğ) tuğlalar bantlardaki işçiler tarafından ranzalara yerleştirilmektedir. Bu aşamada işçiler makine gürültüsüne maruz kalmaktadırlar.

Kurutma aşamasında, ranzalara yerleştirilen yarı mamul tuğlaların firınlanma öncesi kurutma işlemi yapilır. Kurutma açık alanda güneş sıcağından yararlanarak yapılabileceği gibi sıcaklığın ve nemin kontrol altında tutulabildiği özel kurutma odalarında da yapılabilir [12]. Bu üretim yerinde çalışan işçiler açık alanda çalıştıkları için güneş sıcağına ve toza maruz kalmaktadırlar.

Pişirme aşaması, tuğla üretimin en son aşamasıdır. Toprak ürünlerinin suyla çözülemez hale gelmesi, sertlik kazanıp fiziksel ve kimyasal dayanıklılığa sahip olması için pişirilmesi gerekmektedir [3]. Fııınlarda tuğlaların pişiril- mesi için kömür tozu kullanılmaktadır. Tuğlalar, fırınlarda ayrı bölümler haline getirilen kamara olarak ifade edilen bölümlerde pişirilmektedir. Yarı mamul tuğlaların firının içine konulması ve pişirme süreci sonunda firından çıkarılması iş̧̧iler tarafından yapılmaktadır. Bu üretim yeri çalışma şartları bakımından işçiler için en zor kısımdır. Bu üretim yerinde işşiler yüksek sıcaklığa, pişmiş tuğladan kaynaklanan toza ve pişirmede kullanılan kömürün tozuna maruz kalmaktadırlar. Tuğla, pişme sonunda sertleştiği için düşme nedeni ile işçilerin vücutlarının değişik kısımlarında ezilmelere ve kesiklere de neden olmaktadır.

\section{AMAÇ, YÖNTEM VE SINIRLAMALAR}

\section{A. Çalışmanın Amacı}

Çalışmanın amacı, TR 83 bölgesinde yer alan Erbaa ilçesinde üretim faaliyetinde bulunan tuğla fabrikalarında iş sağlığı ve iş güvenliğine yönelik alınan tedbirlerin işçiler tarafından uygulanma düzeylerini ölçmek ve işçilerde ortaya çıkan sağlık problemlerini tespit etmektir.

\section{B. Çalışmanın Yöntemi}

Verilerin elde edilmesinde anket yöntemi kullanılmıştır. Tuğla fabrikaları mevsimsel hava şartlarına ve talebe bağlı olarak çalışan sayılarında farklılık göstermektedir. Araştırmanın yapıldığı dönemde 6 fabrikada toplam 450 iş̧̧ çalışmaktadır. Araştırma için tesadüf örnekleme yöntemi ile seçilen 168 işçiyle yüz yüze görüşülerek anket uygulanmışıtır. Anket formu tasarımında, öncelikle anketi dolduranın bilgilendirilmesi amacıyla anketin amacına ilişkin genel bilgiler verilmiştir. Anket formunda; yaş, cinsiyet, eğitim durumu, işyerinde periyodik sağlık taramasının olması, çalışma ortamında eldiven, gözlük, kulak tıkacı, maske kullanma durumu, işyerinde ilk yardım çantasının bulunulup bulunmadığı gibi sosyodemografik ve iş sağ lı̆̆ı ve güvenliğine yönelik özellikleri sorgulayan sorular yer 
almıştır. Yüz yüze görüşme yöntemiyle anket uygulamasının yapılması anket sonuçlarının güvenilirliğini arttırmıştIr.

\section{C. Çalışmanın Sınırları}

Çalışma Tokat ili Erbaa ilçesindeki tuğla fabrikalarında gerçekleştirilmiştir. Anketler farklı kapasite ve çalışan sayısına sahip 6 adet tuğla fabrikasında uygulanmıştır. Çalışanların, fabrikalarda çalışmaya başlamadan önceki hastalıkları, sigara ve alkol kullanım durumları araştırma dışı bırakılmıştır.

\section{Etik Onay}

Çalışma için, Tokat Gaziosmanpaşa Üniversitesi Sosyal ve Beşeri Bilimler Araştırmaları Etik Kurulundan 04.08.2020 tarihinde 11-17 sayı numarası ile izin alınmıştır.

Bu çalışmanın tüm hazırlanma süreçlerinde etik kurallara ve bilimsel atıf gösterme ilkelerine riayet edildiğini yazar(lar) beyan eder.

\section{BULGULAR}

Erbaa ilçesindeki tuğla fabrikalarının hammadde hazırlama, şekillendirme, kurutma ve pişirme üretim yerlerinde çalışan 168 işçiye uygulanan anketlerden elde edilen bulgular aşağıdaki gibidir.

\section{A. Cinsiyet}

Yapılan işin zorluğu ve tehlikeli olması çalışanların cinsiyetlerini etkilemektedir [21]. Tuğla imalatında çalışma koşullarının ağır olması nedeni ile çalışanların çoğunluğu erkek işgücünden oluşmaktadır.

Tuğla fabrikalarında çalışan işçilerin cinsiyetlerine göre dağılımı Şekil 1'de gösterilmiştir.

Şekil 1'deki grafikten görüldüğü üzere tuğla fabrikala- rında çalışanlarının \%95’i erkek, \%5'i bayan işçilerden oluşmaktadır. Tuğla üretim sürecindeki işlerin yapılma zorluğu nedeniyle bayan işçilerin çalışma oranı düşüktür. Tuğla fabrikalarında çalışan bayan işçilerin fabrika içerisinde çalışma koşullarının hafif olduğu yarı mamul tuğlaların ranzalara yerleştirildiği şekillendirme üretim yerinde çalıştıkları tespit edilmiştir.

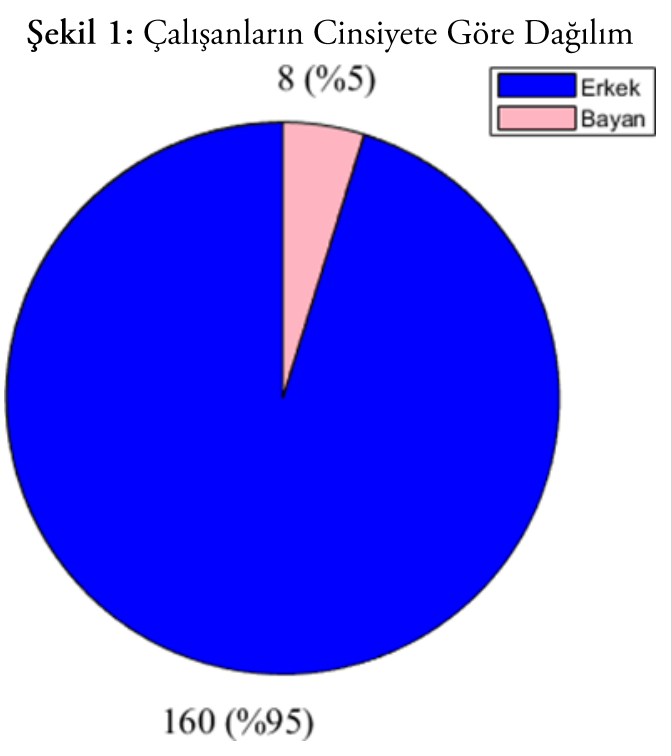

B. Yaş

Tuğla fabrikalarında çalışma şartlarının ağır olması çalışan işçilerin yaş aralığını da etkilemektedir. Tuğla fabrikalarında çalışan işçilerin yaşlarına göre dağılımı Şekil 2'de gösterilmiştir;

Şekil 2'deki grafikte görüldüğü üzere tuğla fabrikalarında çalışan iş̧̧ilerin yaş dağı̆lımı incelendiğinde işçilerin \% 14’ü 20-30, \%40’ 131-40, \%29’u 41-50, \%13’ü 51-60, \% 7 'si 61 ve üzeri yaş grubunda yer almaktadır.

İş̧ilerin çalışma yerleri bakımından yaş dağılımının incelenmesi sonucunda elde edilen veriler Tablo 1'de gösterilmiştir.

Tablo 1'de görüldüğü üzere, hammadde hazırlamadaki işçilerin 6 tanesi (\%43’ü) 20-30, 3 tanesi (\%21’i) 31-40 
arasında, 2 tanesi (\%14’ü) 41-50, 1 tanesi (\%7’si) 61 ve üzeri yaş aralığında yer almaktadır. Preslemedeki işçilerin 8 tanesi (\%19’u) 20-30, 6 tanesi (\%14'ü) 31-40, 13 tanesi (\%31’i) 41-50, 9 tanesi (\%21’i) 51-60 ve 6 (\%14’ü) tanesi 61 ve üzeri yaş aralığındadır. Kurutmadaki işçilerin 3 tanesi (\%19'u) 20-30, 3 tanesi (\%19'u) 31-40, 4 tanesi (\%25'i) 41-50, 6 tanesi (\%38'i) 51-60 yaş aralındadır. Pişirmedeki iş̧̧ilerin 4 tanesi (\%4’ü) 20-30, 54 tanesi (\%56’sı) 31-40, 30 tanesi (\%31’i) 41-50, 8 tanesi (\%8’i) 51-60 yaş aralığındadır. Üretim sürecinin en zor kısmı olan pişirmede çalışan işçilerin \%87’si 31- 50 yaş aralığında olduğu gözükmektedir. Presleme üretim yerinde çalışma şartlarının diğer k1sımlara göre daha hafif olması nedeniyle 20 -30 yaş grubuyla 61 yaş üstü işçilerin çalıştığı gözükmektedir.

Tablo 1: Çalışanların Üretim Yerine Göre Yaş Dağı̆lımı

\begin{tabular}{cccccc}
\multicolumn{5}{c}{ Tablo 1: Çalışanların Üretim Yerine Göre Yaş Dağılımı } \\
\hline & $\begin{array}{c}\text { Hammadde } \\
\text { Hazırlama }\end{array}$ & Presleme & Kurutma & Pişirme & Toplam \\
\hline $20-30$ & 6 & 8 & 3 & 4 & 21 \\
$31-40$ & 3 & 6 & 3 & 54 & 66 \\
$41-50$ & 2 & 13 & 4 & 30 & 49 \\
$51-60$ & 2 & 9 & 6 & 8 & 25 \\
$>=61$ & 1 & 6 & - & - & 7 \\
\hline Toplam & 14 & 42 & 16 & 96 & 168 \\
\hline
\end{tabular}

Şekil 2: Çalışanların Yaş Grubuna Göre Dağılım

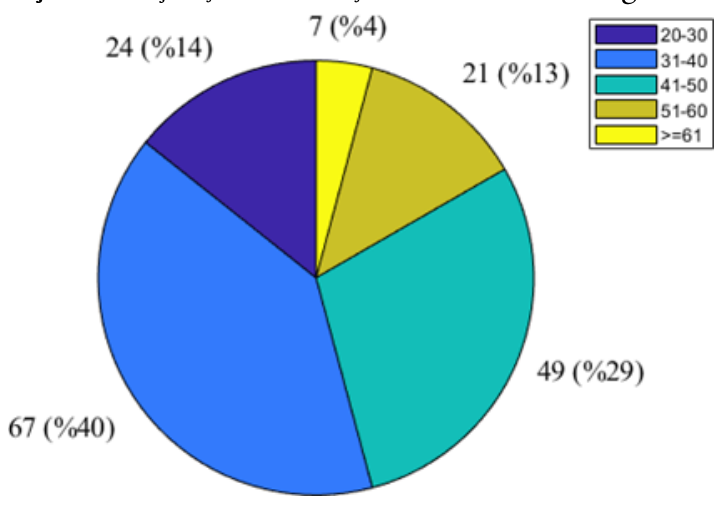

\section{Eğitim}

Tuğla fabrikalarında çalışan işçilerin eğitim durumları ilkokul, ortaokul, lise, ön lisans ve lisans olmaları açısından değerlendirilmiş ve sonuçlar Şekil 3 'te gösterilmiştir.

Şekil 3: Çalışanların Eğitim Durumuna Göre Dağılımı

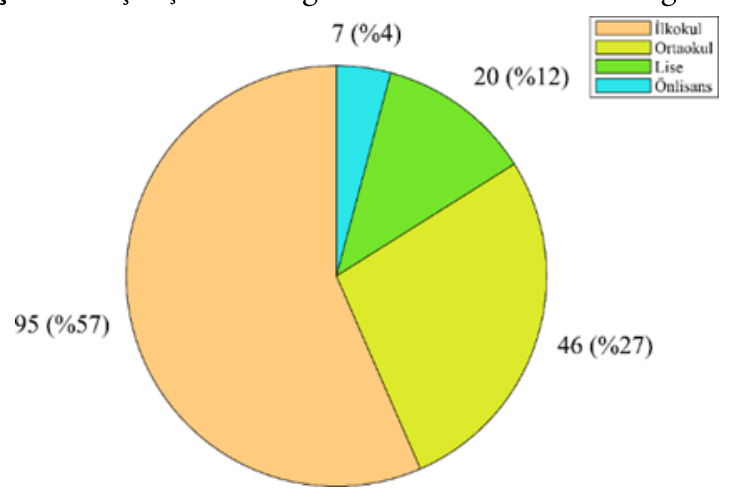

Şekil 3'te görüldüğü üzere tuğla fabrikalarında çalışan işçilerin eğitim durumunun ağırlıklı olarak ilkokul seviyesinde olduğu görülmektedir. Eğitim verilerine göre en fazla \%57'lik oranla ilkokul, \%27'lik oranla ortaokul mezunu oldukları tespit edilmiştir. Eğitim durumu açısından \% 4’lük oranla en az ön lisans mezunu olduğu tespit edilmiştir. Lisans mezunu işçi bulunmadığından grafikte yer verilmemiştir.

\section{D. Çalışılan Bölüm}

Tuğla fabrikalarında çalışan işçilerin fabrika içerisi üretim yerlerinde görev yapmaları açısından değerlendirilmiştir. Elde edilen sonuçlar Şekil 4’te gösterilmiştir.

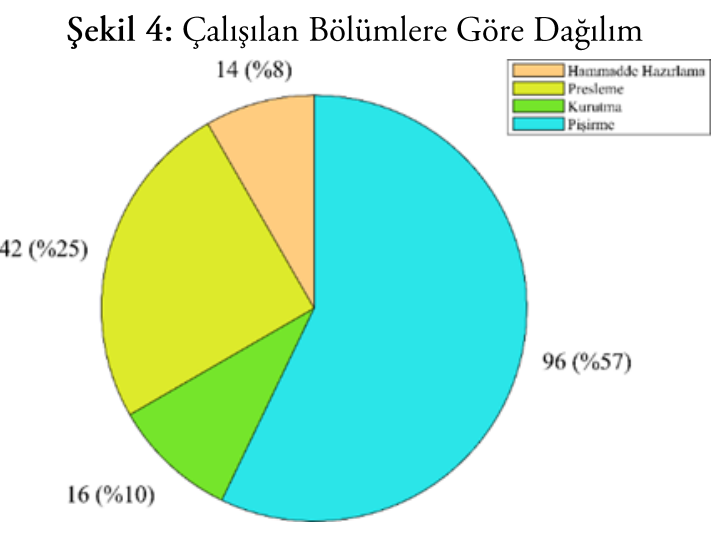


Şekil 4’te görüldüğü üzere anketin \%57'lik oranla en fazla pişirme üretim yerinde çalışan işçilere uygulandığı, en az \%8'lik oranla hammadde hazırlama ve kurutma üretim yerlerinde çalışan işçilere uygulandığı görülmektedir. $\mathrm{Bu}$ dağıllımın oluşmasında üretim yerlerinde çalışan işçi sayıları etkili olmuştur. Emek yoğun üretim yapan tuğla fabrikalarında en fazla işçi pişirme üretim yerinde çalışmakta, daha sonra presleme, kurutma ve hammadde hazırlama olarak sıralanmaktadır.

\section{E. Periyodik Sağlık Taraması}

4857 sayılı İş Kanunu'nun 86. maddesinde "Ağır ve tehlikeli işlerde çalışacak iş̧̧ilerin işe girişinde veya işin devamı süresince en az yılda bir, bedence bu işlere elverişli ve dayanıklı olduklarına dair muayene raporları olmadıkça, bu gibilerin işe alınmaları veya işte çalıştırılmaları yasaktır." denilmektedir. Tuğla fabrikaları da ağır ve tehlikeli iş sınıfında yer almaktadır. Tuğla fabrikalarında çalışan iş̧̧ilerin işyerlerinde periyodik sağlık taramasının yapılıp yapılmadı$\breve{g}_{1}$ ile ilgili değerlendirilmiştir. Değerlendirme sonuçları tablo 2'de gösterilmiştir.

Tablo 2: Periyodik Sağlık Taraması

\begin{tabular}{lcc}
\hline Periyodik Sağlık Tarama Süresi & İşçi Sayısı & Toplam \\
\hline Aylık & - & \\
3 Aylık & - & \\
6 Aylık & - & \\
Yılık & 168 & 168 \\
Tarama Yapılmayan & - & \\
\hline
\end{tabular}

Tablo 2'de görüldüğü üzere tuğla fabrikalarında çalışan tüm işçiler çalışmaya başlamadan önce sağlık taramasından geçirilmişlerdir.

\section{F. İlk Yardım Çantası Bulunma Durumu}

Çalışılan iş yerlerinde ilk yardım çantasının bulunması açısından değerlendirilmiştir. Değerlendirme sonuçları Tablo 3'te gösterilmiştir.
Tablo 3: İlk Yardım Çantası Bulunma Durumu

\begin{tabular}{lcc}
\hline \multirow{2}{*}{ Fabrikalar } & \multicolumn{2}{c}{ ilk Yardım Çantası } \\
& Var & Yok \\
\hline A Fabrikası & + & \\
B Fabrikası & + & \\
C Fabrikası & + & \\
D Fabrikası & + & \\
E Fabrikası & + & \\
F Fabrikası & + & \\
\hline
\end{tabular}

Tablo 3'te görüldüğü üzere fabrikaların hepsinde iş kazası olması durumundan ilk müdahalenin yapılması amacıyla ilk yardım çantası bulundurmaktadırlar.

\section{G. Uyarı Levhaları Bulunma Durumu}

Tuğla üretim yerlerinde iş kazalarına sebep olabilecek tehlikeli alanlar bulunmaktadır. Tuğla üretiminde toprak silosu, atık alanı, elektrik akım alanı, ranza taşıma alanı gibi yerlerde işçiler için iş kazası olacak yerlerdir. Fabrikalarda tehlike oluşturan bu yerlerde uyarı levhaları bulunması gerekmektedir. Tehlike uyarı levhalarının fabrikalarda bulunma açısından değerlendirilmiştir. Fabrika bazında elde edilen sonuçlar Tablo 4’te gösterilmiştir.

Tablo 4: Uyarı Levhaları Bulunma Durumu

\begin{tabular}{lcc}
\hline Fabrikalar & \multicolumn{2}{c}{ Uyarı Levhaları } \\
& Var & Yok \\
\hline A Fabrikası & + & \\
B Fabrikası & + & \\
C Fabrikası & + & \\
D Fabrikası & + & \\
E Fabrikası & + \\
F Fabrikası & + \\
\hline
\end{tabular}

Tablo 4'te görüldüğü üzere fabrikaların hepsi iş kazası riski olan yerlerde uyarı levhaları bulundurmaktadır.

\section{H. Eldiven Kullanma Durumu}

Tuğla fabrikalarında çalışan iş̧̧iler ellerini sıcaktan ve yaralanmalardan korumak için eldiven kullanmaları gerekmektedir. Özellikle firında çalışan işçiler fırından pişmiş tuğlaları çıkartırken sıcağa maruz kalmaktadırlar. Fırındaki 
kamaralardan tuğla çıkarma zamanı geldiğinde 4-in-1 Multi-Function Environment Meter cihazı ile kamera içi sıcaklığını ortalama 550, pişmiş tuğla sıcaklığını ortalama 670 olarak ölçülmüştür. Bu üretim yerinde çalışan işçiler ellerinin sıcaktan zarar görmemesi için eldiven takmaktadırlar. Bunun dışında sertleşen tuğlalar keskinleşerek ellerde kesikler oluşturmakta, metal aksamlar da deriye zarar vermektedir. Çalışan işçilerin ellerini yaralanmaktan ve yanmaktan korumak için eldiven kullanma düzeyleri değerlendirilmiştir. Elde edilen sonuçlar Tablo 5'te gösterilmiştir.

Tablo 5: Eldiven Kullanımı

\begin{tabular}{lcccc}
\hline Üretim Yerleri & $\begin{array}{c}\text { Eldiven } \\
\text { Kullanan iş̧̧i } \\
\text { Sayısı }\end{array}$ & $\begin{array}{c}\text { Eldiven } \\
\text { Kullanmayan } \\
\text { İş̧̧i Sayısı }\end{array}$ & Toplam & $\begin{array}{c}\text { Yüzde } \\
\text { (\%) }\end{array}$ \\
\hline $\begin{array}{l}\text { Hammadde } \\
\text { Hazırlama }\end{array}$ & 9 & 5 & 14 & 64 \\
Şekillendirme & 24 & 18 & 42 & 58 \\
Kurutma & 6 & 10 & 16 & 38 \\
Pişirme & 84 & 12 & 96 & 88 \\
\hline Toplam & 123 & 45 & 168 & 73 \\
\hline
\end{tabular}

Tablo 5'te görüldüğü üzere çalışma yerlerinde eldiven kullanımı bakımından \%88 oranla en fazla pişirme üretim yerinde uygulanmaktadır. Burada çalışan işçiler pişmiş tuğlanın sıcaklık ve kesme riskine maruz kalmaktadırlar. Çalışma rahatlığı sağladığı için pişirme üretim yerinde çalışan işçilerin büyük çoğunluğu eldiven kullanmaktadır. Hammadde hazırlamada \%64, kurutma ve şekillendirme üretim yerinde \%58 oranında eldiven kullanılmaktadır. Fabrika geneli baz alındığında işçilerin \%73'ü eldiven kullanmaktadır. İş sağlığı ve güvenliği kuralları açısından en fazla eldiven kullanılarak uyulmaktadır.

\section{İ. Kulak Tıkacı Kullanma Durumu}

Tuğla fabrikalarının üretim yerlerinde kullanılan makinelerin çalışmalarına bağlı olarak oluşan gürültü sesi işçileri rahatsız etmektedir. Çalışan işçilerin üretim yerlerinde kulak tıkacı kullanmaları değerlendirilmiştir. Elde edilen so- nuçlar Tablo 6'da gösterilmiştir.

Tablo 6: Kulak Tıkacı Kullanma Durumu

\begin{tabular}{lcccc}
\hline Üretim Yerleri & $\begin{array}{c}\text { Kulak Tıkacı } \\
\text { Kullanan İşçi } \\
\text { Sayısı }\end{array}$ & $\begin{array}{c}\text { Kulak Tıkacı } \\
\text { Kullanmayan } \\
\text { İşçi Sayısı }\end{array}$ & Toplam & $\begin{array}{c}\text { Yüzde } \\
\text { (\%) }\end{array}$ \\
\hline $\begin{array}{l}\text { Hammadde } \\
\text { Hazırlama }\end{array}$ & 2 & 12 & 14 & 14 \\
Şekillendirme & 18 & 24 & 42 & 43 \\
Kurutma & - & 16 & 16 & - \\
Pişirme & - & 96 & 96 & - \\
\hline Toplam & 20 & 148 & 168 & 12 \\
\hline
\end{tabular}

Tablo 6'da görüldüğü üzere şekillendirme üretim departmanında çalışan işçilerin \%43'ü, hammadde hazırlamada departmanında çalışan işçilerin \%14’ü, fabrikalarda çalışan toplam işçilerin açısından değerlendirildiğinde \% 12'si kulak tıkacı kullanmaktadır. Kulak tıkacı kullanma oranı genelde düşük seviyede bulunmuştur. Başka bir çalışma ile işçiler duyma testinden geçirilerek tıkaç kullanmamanın yan etkileri araştırılabilir.

\section{J. Koruyucu Gözlük Kullanma Durumu}

Koruyucu gözlük işçilerin çalışma anında gözlerinde oluşacak yaralanmaların ve göz hasarlarının engellenmesi için kullanılmaktadır. Tuğla fabrikalarında çalışan işçilerin çalışma alanlarında koruyucu gözlük kullanmaları değerlendirilmiş, elde edilen sonuçlar Tablo 7’de gösterilmiştir.

Tablo 7: Koruyucu Gözlük Kullanma Durumu

\begin{tabular}{lcccc}
\hline Üretim Yerleri & $\begin{array}{c}\text { Koruyucu } \\
\text { Gözlük } \\
\text { Kullanan İşçi } \\
\text { Sayısı }\end{array}$ & $\begin{array}{c}\text { Koruyucu } \\
\text { Gözlük } \\
\text { Kullanmayan } \\
\text { İş̧̧i Sayısı }\end{array}$ & Toplam & $\begin{array}{c}\text { Yüzde } \\
\text { (\%) }\end{array}$ \\
\hline Hammadde & 2 & 12 & 14 & 14 \\
Hazırlama & 8 & 34 & 42 & 19 \\
Şekillendirme & - & 16 & 16 & - \\
Kurutma & - & 96 & 96 & - \\
Pişirme & 10 & 158 & 168 & 6 \\
\hline Toplam & & & &
\end{tabular}

Tablo 7'de görüldüğü üzere hammadde hazırlamada çalışan işçilerin \%14'ü, şekillendirmede çalışan işçilerden \%19'u, toplam çalışan işçilerin \%6'sı koruyucu gözlük 
kullanmaktadır. Hammadde hazırlama üretim yerinde toprağın içerisindeki taşların ayıklandığı ve öğütüldüğü kısımda çalışan işçilerin koruyucu gözlük taktığı, şekillendirme üretim yerinde kaynak yapan işçilerin kaynağın gözlere zarar vermemesi için koruyucu gözlük kullandığı tespit edilmiştir. Tuğla fabrikalarının diğer üretim yerlerinde çalışan işçilerin koruyucu gözlük kullanmadıkları tespit edilmiştir.

\section{K. Şapka Kullanma Durumu}

Açık alanda çalışan işçilerin güneşin zararlı etkilerinden korunmak için şapka takmaları gerekmektedir. Tuğla fabrikalarında üretim yapılan yerlerinin bazıları kapalı alan bazıları da açık alandır. Çiğ tuğlaların fırınlarda pişirilmeden önce açık alanda güneş sıcaklığından yararlanarak kurutulmaları gerekmektedir. Kurutma üretim yerlerinde çalışan işçiler ile hammadde hazırlama kısmında çalışan işçiler güneş ışı̆̆ına maruz kalmaktadır.

Pişirme aşamasında çalışan işçilerin bir kısmı fırın içinde bir kısmı da fırın dışında çalışmaktadır. Fırın dışı alanda çalışan işçilerde güneş ışığına maruz kalmaktadır. Tuğla fabrikalarında çalışan işçilerin şapka kullanma açısından değerlendirme sonuçları Tablo 8'de gösterilmiştir.

Tablo 8: Sapka Kullanım Durumu

\begin{tabular}{lcccc}
\hline Üretim Yerleri & $\begin{array}{c}\text { Şapka } \\
\text { Kullanan İşçi } \\
\text { Sayısı }\end{array}$ & $\begin{array}{c}\text { Şapka } \\
\text { Kullanmayan } \\
\text { Işçi Sayısı }\end{array}$ & Toplam & $\begin{array}{c}\text { Yüzde } \\
\text { (\%) }\end{array}$ \\
\hline $\begin{array}{l}\text { Hammadde } \\
\text { Hazırlama }\end{array}$ & 8 & 6 & 14 & 57 \\
Şekillendirme & 4 & 38 & 42 & 10 \\
Kurutma & 12 & 4 & 16 & 75 \\
Pişirme & 32 & 64 & 96 & 33 \\
\hline Toplam & 56 & 112 & 168 & 33 \\
\hline
\end{tabular}

Tablo 8'de görüldüğü üzere kurutma üretim yerinde çalışan işçilerin \%75'i, hammadde hazırlama üretim yerinde çalışan işçilerin \%57'si, pişirme üretim yerinde çalışan işçilerin \%33'ü şapka kullanmaktadır. Toplam işçilere ba- kıldığında şapka kullanın oranın \%33 olduğu tespit edilmiştir.

\section{Maske Kullanma Durumu}

Tuğla fabrikalarında çalışan işçiler çalışma ortamında en fazla firınlarda tuğla tozuna ve kömür tozuna maruz kalırlar. Bu tozlar burunda, kulaklarda ve akciğerde rahatsızlık oluşturabilirler. Bu tozların etkilerinden korunmak için işçilerin maske kullanmaları gerekmektedir. Çalışanların üretim yerlerinde maske kullanmaları açısından değerlendirilmiş ve elde edilen sonuçlar Tablo 9'da gösterilmiştir.

Tablo 9'da görüldüğü üzere üretim yerleri bakımından en fazla maske kullanımı \%39 oranla pişirme üretim yerindedir. Burada çalışan iş̧̧iler pişmiş tuğla tozuna ve pişirmede kullanılan kömür tozuna maruz kalmaktadırlar. Tuğla ve kömür tozunun sağlıklarına zarar verdiklerini bildikleri halde maske kullanmayan işçilerde bulunmaktadır. Maske kullanmayan işçiler fabrikalar tarafından maske verildiği ancak fırın içerisinde ve dışında çalışırken maskelerin rahat nefes almaya imkân vermediği için maske kullanmadıklarını ifade etmişlerdir. Kurutma departmanında çalışan işçilerin $\% 25$ ' $\mathrm{i}$, şekillendirme departmanında çalışan işçilerin \% 12'si maske kullanmaktadır. Toplam işçiler bazında maske kullanım oranının \%27 olduğu tespit edilmiştir.

Tablo 9: Çalışanların Maske Kullanımı

\begin{tabular}{lcccc} 
Üretim Yerleri & $\begin{array}{c}\text { Maske } \\
\text { Kullanan isçci } \\
\text { Sayısı }\end{array}$ & $\begin{array}{c}\text { Maske } \\
\text { Kullanmayan } \\
\text { İşçi Sayısı }\end{array}$ & Toplam & $\begin{array}{c}\text { Yüzde } \\
\text { (\%) }\end{array}$ \\
\hline $\begin{array}{l}\text { Hammadde } \\
\text { Hazırlama }\end{array}$ & - & 14 & 14 & - \\
$\begin{array}{l}\text { Şekillendirme } \\
\text { Kurutma }\end{array}$ & 5 & 37 & 42 & 12 \\
Pişirme & 4 & 12 & 16 & 25 \\
\hline Toplam & 37 & 59 & 96 & 39 \\
\hline
\end{tabular}


Tablo 10: Sağlık Problem Bulguları

\begin{tabular}{|c|c|c|c|c|}
\hline Sağlık Problemleri & Hammadde Hazırlama & Şekillendirme & Kurutma & Pişirme \\
\hline \multicolumn{5}{|l|}{ Kas Eklem Ağrıları } \\
\hline$\Rightarrow$ Omuz & 3 & 7 & 4 & 17 \\
\hline$\Rightarrow$ Boyun & - & - & 3 & 10 \\
\hline$\Rightarrow \mathrm{El}$ & - & 5 & - & 12 \\
\hline$\Rightarrow \mathrm{Diz}$ & - & - & - & 9 \\
\hline$\Rightarrow$ sırt & - & 4 & 3 & 26 \\
\hline Öksürük & 4 & 6 & 3 & 19 \\
\hline Balgam Çıkarma & 2 & 6 & 5 & 34 \\
\hline Nefes Darlığı & - & 5 & 4 & 11 \\
\hline Tanısı Konmuş Astım Bronşit & - & - & 1 & 7 \\
\hline Vücutta Yara & - & - & 3 & 4 \\
\hline Kesik & - & - & - & 6 \\
\hline Ezilme & & - & 3 & 6 \\
\hline Burundan Kan gelme & - & - & - & 3 \\
\hline
\end{tabular}

\section{Sağlık Problemleri Bulguları}

Sektörlerin üretim özelliklerine göre çalışanlarda çeşitli sağılı problemleri ortaya çıkmaktadır. İşçi sağlığı ve güvenliği için alınacak tedbirlerle çalışanlarda ortaya çıkacak sağlik problemleri engellenebilir veya en az seviyede ortaya çıkabilir. Tuğla fabrikalarında çalışan iş̧̧ilerde ortaya çıkan kas ve eklem ağrıları, öksürük, balgam çıkarma, ağızdan kan gelme, nefes darlığı, ciltte yara gibi çalışma şartlarına bağlı olarak oluşabilecek sağlık problemleri değerlendirilmiş ve elde veriler Tablo 10 'da gösterilmiştir.

Tablo 10 'da görüldüğü üzere, üretim yerlerinde çalışan işçilerde ortaya çıkan sağlık problemleri ayrı ayrı gösterilmiştir. Pişirme üretim yerinde çalışan iş̧̧ilerde ortaya çıkan sağlık problemleri diğer üretim yerlerine göre daha fazladır. Pişirme üretim yerinde çalışma şartlarının ağır olması sağlık problemlerinin de fazla çıkmasında etkili olmuştur. Kurutma, şekillendirme ve hammadde hazırlama üretim yerlerinde çalışan iş̧̧ilerde de sağlık problemleri çıkmış ancak pişirme üretim yerine göre kıyaslandığında görülme sıklığı daha az görülmüş̧ür.
Kas ve eklem ağrılarından omuz ağrısı üretim yerlerinin hepsinde, sırt ağrısı hammadde hazırlama dışındaki üretim yerlerinde, diz ağrısı pişirme üretim yerlerinde çalışanlarda oluştuğu tespit edilmiştir.

Öksürük ve balgam çıkarma fabrika genelinde çalışan iş̧̧ilerde ortaya çıkmıştır. Çalış̧an işçilerin 32 tanesi öksürük, 47 tanesi balgam çıkarma sorunu olduğunu ifade etmişlerdir. Toza maruz kalmanın fazla olduğu pişirme üretim yerinde çalışan işçilerde solum yolu rahatsızlıkları daha fazla ortaya çıkmıştır. Pişirme üretim yerinde çalışanların üçte birinden daha fazlası balgam çıkarma sorunu yaşamaktadır. Öksürük ve balgam çıkarma sorunu yaşayan 7 işçi dışında kalanların maske kullanmadıkları tespit edilmiştir.

Astım ve bronşit rahatsızlığı teşhisi konmuş 8 işçi olduğu, bunların 7'sinin pişirme üretim yerinde çalıştığı ve maske kullanmadıkları tespit edilmiştir. Sonuçlara bakıldığında tuğla ve kömür tozuna maruz kalıp maske kullanmayan iş̧̧ilerde solunum yolu rahatsızlığı oluştuğu tespit edilmiştir.

Vücutta yara çıkmayla ilgili 7 iş̧̧inin sağlık problemi 
yaşadığı tespit edilmiştir. Bunların 4’ü fırında, 3’ü kurutma kısmındaki işçilerdir. Yara çıkma problemi yaşayan işçiler sıcağın etkili olduğu fırın ve kurutma kısmında çalışmaktadırlar. Fırında oluşan sıcaklık etkisi ile güneş ışınlarının yaymış olduğu sıcaklık etkisi yanık ve yara problemine neden olmaktadır.

Kesik ve ezilme durumları açısından değerlendirildiğinde 6 işçinin kesik, 9 işçinin de ezilme sorunu yaşamıştır. Kesik sorunu olan işçiler pişirme yerinde, ezilme sorunu yaşayan işçilerin 6 tanesi pişirme, 3 tanesi kurutma yerinde çalıştıkları tespit edilmiştir. Kesiklerin eldiven kullanılmaması sonucu, eziklerin pişmiş tuğlaların düşmesi ve çarpması sonucu oluştuğu tespit edilmiştir.

\section{SONUÇ}

Erbaa ilçesinde üretim faaliyetinde bulunulan 6 adet tuğla fabrikasında hammadde hazırlama, şekillendirme, kurutma ve pişirme üretim yerlerinde çalışan işçilerle anket yöntemi kullanılarak yapılan iş sağlığı ve güvenliğine yönelik alınan tedbirlerin uygulama düzeylerinin ve ortaya çıkan sağlık problemlerinin araştırıldığı çalışma sonucunda, tuğla fabrikalarının çalışma şartlarının ağır olması nedeniyle çalışanların cinsiyet ve yaş grubunu etkilediği tespit edilmiştir. Çalışanların \%95 erkek, \%70’i 31-50 yaş aralığında, \%84'nün ilköğretim düzeyinde eğitime sahip olduğu tespit edilmiştir.

Tuğla fabrikalarında çalışacak işçilerin sağlık taramasından geçirildikten sonra işe başlatıldıkları, işyerlerinin hepsinde iş kazasında ilk tedaviyi yapmak üzere ilk yardım çantası bulunduğu, işyerlerinin tamamında iş kazasına neden olacak yerlerde uyarıcı levhaları olduğu tespit edilmiştir.

Tuğla fabrikalarında çalışan işçilerin iş sağlığı ve güvenliğine yönelik tedbirlere uymayla ilgili olarak maske, eldi- ven, koruyucu gözlük, kulak tıkacı, şapka kullanma durumları değerlendirilmiştir. Maske kullanma durumuna göre fabrika genelinin \%27'si, pişirme departmanının \% 39'u, kurutmanın \%25'i maske takmaktadır. Eldiven takma durumu açısından fabrika genelinin \%73'ü, pişirme üretim yerinde çalışan işçilerin \%88'i eldiven takmaktadır. Ciltte yara ve yanık oranının az çıkmasının sebebi eldiven takma uygulamasına uyulması etkili olmuştur. Kulak tıkacı kullanmanın en fazla oranda şekillendirme üretim yerindeki olduğu tespit edilmiştir. Koruyucu gözlük kullanımı en fazla kaynak işçileri tarafından ve hammadde hazırlamadaki işçiler tarafından kullanılmaktadır.

Anket sonuçlarına göre işçilerde ortaya çıkan sağlık sorunlarından kas ve eklem ağriları, omuz ve sırt ağrısı çalışma şartlarına bağlı olarak üretim yerlerinin hemen hemen hepsinde ortaya çıktığı tespit edilmiştir.

İşçilerde en fazla sağlık problemi solunum yollarına bağlı rahatsızlıklardan oluşmaktadır. Özellikle pişirme üretim yerinde tuğla tozuna maruz kalan işçilerde daha fazla solunum yolu rahatsızlığı olduğu tespit edilmiştir. Pişirme üretim yerinde çalışanların \%34'ünde balgam çıkarma, \% 11 'inde nefes darlı̆̆ı olduğu, 7 işçiye de astım bronşit teşhisi konduğu tespit edilmiştir. Solunum yolu rahatsızlı̆̆ının fazla çıkmasında maske kullanım oranının düşük olmasının etkili olduğu düşünülmektedir. Solunum yolu rahatsızlığı olan işçilerin çoğunluğunun maske kullanmadıkları tespit edilmiştir. Pişirme üretim yerinde çalışanların tamamı toza maruz kaldıkları için maske kullanım oranının pişirme üretim yerinde \%39 olması yeterli olmamaktadır. Maske kullanım oranının yeterli olmadığı solunum yolu rahatsızlık verilerinin yüksek çıkmasından da anlaşılmaktadır. Diğer üretim yerlerine göre daha fazla tuğla ve kömür tozuna maruz kalmaları nedeniyle pişirme üretim yerinde çalışan bütün işçilerin maske kullanmaları sağlanmalıdır. İşçiler, kullanılan maskelerin rahat nefes almalarına imkân verme- 
diğini gerekçe göstererek maske kullanmadıklarını ifade etmişlerdir. Kişisel Koruyucu Donanımların İşyerlerinde Kullanılması Hakkında Yönetmelik gereği, işverenler çalışma şartlarına uygun kişisel koruyu donanım bulundurma yükümlülüğü bulunmakta, ancak kullanım için yasal zorunluluk bulunmamaktadır Maske kullanımını artırmak için işletmeler, maske üreten firmalarla görüşüp daha ergonomik maske modelleri ürettirmeleri, işverenlerin maske kullanımının hangi risklere karşı koruyucu olduğu ile ilgili bilgilendirme toplantıları yapmaları, riskli alanlarda maske kullanımını zorunlu hale getirmeleri gibi uygulamalar yapabilirler.

Konu ile ilgili olarak araştırma yapacaklara, çalışanların iş sağıllığı ve iş güvenliği bilgi düzeylerini ölçecek, sektörde çalışmadan önceki sağlık durumları ile çalışmaya başladıktan sonra ortaya çıan sağlık problemlerinin tespitine yönelik sağlık bilimlerinde derinlemesine araşıırmalar yapılarak sağlık sorunları daha detaylı incelenebilir. Ayrıca işs sağlığı ve iş güvenliğine uyulmamasının, çalışanlarda ortaya çıkan sağlık problemlerinin bölgesel farklılığın olup olmadığını araştırmak içinde farklı bölgelerdeki tuğla fabrikalarında araştırmalar yapılabilir.

YaZAR KatKILARI: Yazarların katkıları eşit düzeydedir.

Çıikar Çatışması: Yazarlar herhangi bir çıkar çatışması olmadığını, makalede araştırma ve yayın etiğine uyulduğunu beyan ederler.

Finansal Destek: Bu çalışmada herhangi bir kişi, kurum veya kuruluştan finansal destek alınmamışıır.

Етік Коміте Onayı: Çalışma için, Tokat Gaziosmanpaşa Üniversitesi Sosyal ve Beşeri Bilimler Araştırmaları Etik Kurulundan 04.08.2020 tarihinde 11-17 sayı numarası ile izin alınmıştır.

\section{KAYNAKÇA}

[1] Aktuna, A., Aktuna, A., 2017. İnşaat Sektöründe İş Sağglı̆ı ve Güvenliği: Tekirdağ Süleymanpaşa Örneği, III. IBANESS Kongreler Serisi, 04-05 Mart, Edirne, 1394-1406.

[2] Ateş, Metin. (2013) Sağllk Hizmetleri Yönetimi, beta yayınları 2. Baskı İstanbul.

[3] Bacioğlu, A., Bacioğlu, S. (2013) Tuğla ve Kiremit Üretim, Yatırım, İşletme. Yaman Ofset.

[4] Balkır, Z, Gönül. (2012). İşs sağlığı ve güvenliği hakkının korunması: İşverenin iş sağlığı ve güvenliği organizasyonu, Sosyal Güvenlik Dergisi, s 56-91.

[5] Devebakan, N. (2007). Özel Sağlık İşletmelerinde İşs Sağlığı ve Güvenliği, DEÜ Sosyal Bilimler Enstitüsü. Bastırılamamış Doktora Tezi, İzmir .

[6] İş Sağlığı ve Güvenliği Genel Müdürlüğü (2020), İstatistiklerle Türkiye’nin İSG Görünümü, Ankara.

[7] İş Sağlığı ve Güvenliği Kanunu (2012), T.C. Resmi Gazete, 28339, 20 Haziran 2012.

[8] Karacan, E., Erdoğan, Ö.N. (2011). İşçi Sağlığı ve İş Güvenliğine İnsan Kaynakları Yönetimi Fonksiyonları Açısından Çözümsel Bir Yaklaşım. Kocaeli Üniversitesi Sosyal Bilimler Enstitüsü Dergisi, s 102-117.

[9] Erginel, N ve Toptancı, Ş. (2017). İş Kazası Verilerinin Olasılık Dağılımları ile Modellenmesi, Mühendislik Bilimleri ve Tasarım Dergisi, s 201-212.

[10] Kılkış, İ.(2016). İş Sağlığı ve Güvenliği, Dora Yayınlar1, Bursa.

[11] Öcal, A (2009). Sağlık çalışanlarında İş sağlığı ve Güvenliği. Beykent üniversitesi, Sosyal Bilimler Enstitüsü, Yüksek Lisans Tezi. İstanbul.

[12] Öneş, A. (1988). İnşaat Malzeme Bilgisi. Ankara Üniv. Ziraat Fakültesi Yayınları:1094, Ankara.

[13] Öztürk, H., Babacan, E., Özdaş, E. (2012) Hastanede Çalışan sağlık Personelinin İş Güvenliğii, Gümüşhane üniversitesi, Journal Of Health Sciences, 1 (4), s 252-268.

[14] Sosyal Sigortalar ve Genel Sağlık Sigortası Kanunu (2006), T.C. Resmi Gazete, 26200,16 Haziran 2016.

[15] Pala, K (2005). ISG Politikası ve Güvenlik kültürü. İş Sağlığı ve Güvenliği Dergisi, 5(25)

[16] Songur, L, Songur, Gökçen. (2018). Ekonomik Büyümede İş Kazası ve Meslek Hastalıklarının Önemi ve Sosyal Tarafların Sorumlulukları. Akademik bakış dergisi. Say1 68

[17] Şişman, C., B., Kocaman, İ., Gezer, E., (2006). Te- 
kirdağ Yöresinde Üretilen ve Tarımsal Yapılarda Yaygın Olarak Kullanılan Tuğlanın Fiziksel ve Mekanik Özellikleri Üzerine Bir Araştırma. Tekirdağ Ziraat Fakültesi Dergisi 3(1), s 32-40.

[18] Tarım, M. (2017). Kimya Sektöründe İş Kazaları ve Meslek Hastalıkları. İstanbul Commerce University Journal of Science. 16 (32), s 49-64.

[19] Temel, E. (2017). Kümelenmenin Toprak Sanayinde Üretim Maliyetlerine Etkisi Üzerine Bir Araştırma TR 83 Bölgesi Erbaa Örneği. Tokat. Gaziosmanpaşa Üniversitesi SBE Doktora Tezi.

[20] Temel, E. ve Ertaş, F.C., (2018). TR 83 Bölgesinde Kümelenmenin Üretim Maliyetlerine Etkisi Toprak Sanayi Örneği. Muhasebe ve Denetime Bakış Dergisi, Say1 54, s 35-56.

[21] Temel, E ve Aydoğdu, E.T. (2019). Analysis Of Labor Profile İn The Brick Sector, Social Sciences Researches Journal, 14(2), s 143-156.

[22] Tmmob (2018). İş Sağlığı İş Güvenliği Oda Raporu. İstanbul.

[23] Tunçer, P. (2011). İnsan Kaynakları Yönetimi, Ekin Yayınları, Bursa. 